Int. J. Dev. Biol. 55: 313-319 (2011)

doi: $10.1387 / \mathrm{ijdb} .1032401 \mathrm{v}$

\title{
Co-localization of neural cell adhesion molecule and fibroblast growth factor receptor 2 in early embryo development
}

\author{
LISELOTTE VESTERLUND*,1, VIRPI TÖHÖNEN1 ${ }^{1}$, OUTI HOVATTA² and JUHA KERE1,3,4 \\ ${ }^{1}$ Department of Biosciences and Nutrition, Karolinska Institutet, Huddinge, Sweden, ${ }^{2}$ Department of Clinical Science, \\ Intervention and Technology, Karolinska Institutet, Karolinska University Hospital Huddinge, Stockholm, Sweden, \\ ${ }^{3}$ Folkhälsan Institute of Genetics, Helsinki, Finland and ${ }^{4}$ Department of Medical Genetics, University of Helsinki, Finland.
}

\begin{abstract}
During development there is a multitude of signaling events governing the assembly of the developing organism. Receptors for signaling molecules such as fibroblast growth factor receptor 2 (FGFR2) enable the embryo to communicate with the surrounding environment and activate downstream pathways. The neural cell adhesion molecule (NCAM) was first characterized as a cell adhesion molecule highly expressed in the nervous system, but recent studies have shown that it is also a signaling receptor. Using a novel single oocyte adaptation of the proximity ligation assay, we here show a close association between NCAM and FGFR2 in mouse oocytes and 2-cell embryos. Real-time PCR analyses revealed the presence of messenger RNA encoding key proteins in downstream signaling pathways in oocytes and early mouse embryos. In summary these findings show a co-localization of NCAM and FGFR2 in early vertebrate development with intracellular signaling pathways present to enable a cellular response.
\end{abstract}

KEY WORDS: NCAM, FGFR2, mouse, PLA, development

Growth factors, such as fibroblast growth factors (FGFs) are crucial for the embryo development and the presence of FGF receptors in the developing oocyte have been shown in several vertebrate species (Ben-Haroush et al., 2005, Cailliau et al., 2003, Yoshida et al., 1998). There are four well-characterized FGF receptors (FGFRs 1-4), which contain a single transmembrane domain, an intracellular tyrosine kinase domain, and an extracellular FGF binding domain composed of two or three immunoglobulin (lg)-like domains. The transcripts encoding FGF receptor 2 (FGFR2) are alternatively spliced to produce two FGFR2 transcripts (FGFR2-1 and FGFR2-2) that translate into two proteins with different carboxy-terminal halves of the Ig-III domain. This domain is determined by the inclusion of either exon IIIb (FGFR2-2) or exon IIIC (FGFR2-1), which controls ligandbinding specificity (Miki et al., 1992).

Cell adhesion molecules (CAMs) are cell surface molecules responsible for mediating adhesion of cells to other cells and/or the extracellular matrix. The neural cell adhesion molecule (NCAM) is a member of the immunoglobulin superfamily and it is found in three major isoforms (Hinsby et al., 2004). The extracellular part of the NCAM consists of five Ig-like domains and two fibronectin type III (F3) domains. The two larger isoforms (NCAM-180 and NCAM-140) are transmembrane proteins, while the third NCAM120 isoform is attached to the cell membrane. Different functions for the three isoforms have been suggested (Polo-Parada et al., 2004). NCAM has mainly been described as a modulator of migration, axon growth and axon fasciculation in the developing brain (Hansen et al., 2008a), but expression in mouse oocytes and early embryos have also been shown (Lu et al., 2002).

Recent studies have shown that NCAM also function as signaling receptor via interactions with a number of other cell surface receptors such as growth factor receptors (Maness and Schachner, 2007). Also, non-tyrosine kinase receptors or cellsurface FGFR-interacting proteins are important players in FGF signaling (Murakami et al., 2008). One of the most studied signaling pathways is the mitogen-activated protein kinase (MAPK

\footnotetext{
Abbreviations used in this paper: ERK, extracellular receptor kinase; FGF, fibroblast growth factor; FGFR, fibroblast growth factor receptor; Ig, immunoglobulin; MAPK, mitogen-activated protein kinase; NCAM, neural cell adhesion molecule; PLA, proximity ligation assay.
}

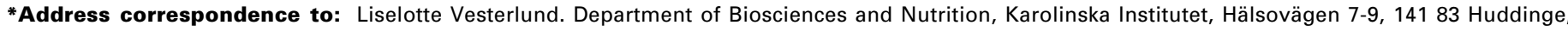
Sweden. Fax: +46-8-774-5538. E-mail: liselotte.vesterlund@ki.se
} 
or extracellular receptor kinase, ERK) pathway that is thought to play an important role in various cellular events, including cell differentiation and regulation of embryonic development. NCAM has been shown to activate the MAPK pathway in neuronal cells (Schmid et al., 1999).

During our studies of early development we observed that both NCAM and FGFR2 are expressed on mRNA level (Table 1) and this observation lead us to investigate whether the proteins were present and if so where the proteins could be located in the oocyte and early embryo. NCAM and FGFR1 have been studied extensively and the interaction between FGFR1 and NCAM is well characterized (Kiselyov, 2010). However, the binding of NCAM to FGFR2 has not been described to the same extent. Although an in vitro binding between recombinant NCAM and immobilized recombinant FGFR2 have been previously described (Christensen et al., 2006) this is the first time that NCAM and FGFR2 are shown to be in close proximity to each other in vivo making interaction between the two proteins during early development plausible. Christensen et al., (2006) have shown that recombinant NCAM may bind to recombinant FGFR2 in an in vitro system using the two F3 domains of NCAM and immobilized Ig-like domains 2-3 of FGFR2. This study shows the co-localization of NCAM and FGFR2 in mouse oocytes and early embryos using a novel single oocyte adaptation of the proximity ligation assay (PLA) method (Soderberg et al., 2006). In addition, the presence of messenger RNAs (mRNA) encoding key components of signaling pathways downstream of these two receptors are studied, and the possible function of NCAM and FGFR2 signaling in early development is discussed.

\section{Results and Discussion}

First the localization of NCAM and FGFR2 was determined using primary antibodies recognizing either intracellular epitopes of NCAM or FGFR2. NCAM (Fig. 1B) and FGFR2 (Fig. 1D) were detected in the oocyte membrane. In addition, the membrane localization of the proteins was confirmed using primary antibodies recognizing extracellular epitopes of NCAM (Fig. 2B) or FGFR2 (Fig. 2D).

To determine if NCAM and FGFR2 co-localize, an adaptation of the PLA technique for detection of protein co-localization in single oocytes and early embryos was used. Co-localization of NCAM and FGFR2 in oocyte membrane could be shown using pairs of specific primary antibodies directed against each of the two target proteins (Fig. 3). Specific signals could be observed in the oocyte membrane, as shown by a series of confocal images (Fig. 3B). The same patterns of membrane-localized signals were observed using a pair of primary antibodies recognizing extracellular epitopes of NCAM and FGFR2 (Fig. 3D). Since the PLA will only detect proteins in close proximity of each other the presence of signal indicates that NCAM and FGFR2 are co-localizing in the mouse oocyte membrane. NCAM may activate intracellular signaling pathways such as protein kinase $A$, protein kinase $C$ (PKC) and the Ras-MAPK pathway (Ditlevsen et al., 2008). Although all three NCAM isoforms are redundant for embryo viability (Cremer et al., 1994) a secreted construct of the extracellular NCAM domain has been shown to result in embryonic lethality (Rabinowitz et al., 1996). Thus it appears that NCAM in the extracellular environment can generate signals that affect early development.
TABLE 1

\section{MICROARRAY EXPRESSION DATA (HG-U133_PLUS2, AFFYMETRIX) OF NCAM AND FGFR2 MRNA EXPRESSION DURING EARLY HUMAN DEVELOPMENT}

\begin{tabular}{|c|c|c|c|c|c|c|c|}
\hline \multirow[b]{3}{*}{ mRNA } & \multirow[b]{3}{*}{ Ref_seq } & \multicolumn{6}{|c|}{ Developmental stage } \\
\hline & & \multicolumn{3}{|c|}{ Oocyte } & \multicolumn{3}{|c|}{ Embryo } \\
\hline & & GV & MI & MII & D2 & D3 & D5 \\
\hline NCAM isoform 1 and/or 2 & $\begin{array}{l}\text { NM_000615.5 } \\
\text { NM_181351.3 }\end{array}$ & ++ & ++ & ++ & ++ & ++ & ++ \\
\hline NCAM isoform 3 & NM_001076682.2 & $+^{*}$ & $+^{*}$ & $t^{*}$ & $t^{*}$ & $t^{*}$ & $t^{*}$ \\
\hline FGFR2 & $\begin{array}{l}\text { NM_000141.4 } \\
\text { NM_022970.3 }\end{array}$ & ++ & ++ & ++ & ++ & $++^{*}$ & $++^{*}$ \\
\hline
\end{tabular}

The + indicates relative expression levels. The * indicates significant difference in expression levels when compared to NCAM isoforms 1 and 2 (Student's t-test, $\mathrm{p}<0.05$ ). The HG-U133_plus2 array probe sets do not differ between NCAM isoform 1 and 2, or the different FGFR2 isoforms. GV: Germinal Vesicle; MI: Oocyte stage MI; MII: Oocyte stage MII; D2: Day 2 embryo; D3: Day 3 embryo; D5: Day 5 embryo. (For microarray database see Zhang et al., 2009)

TABLE 2

\section{PRIMERS USED FOR NCAM AND FGFR2 EXPRESSION ANALYSIS}

\begin{tabular}{llc} 
Primer & Primer sequence (5'-3') & Product size \\
\hline Fgfr2-1F & 5'-CGGCCTCTATGCTTGTACTG-3' & $122 \mathrm{bp}$ \\
Fgfr2-1R & 5'-CGTCTTCGGAGCTATCTGTGT-3' & \\
Fgfr2-2F & 5'-GGATCAAGCACGTGGAAAAG-3' & $133 \mathrm{bp}$ \\
Fgfr2-2R & 5'-TCCATCTCCGTCACATTGAA-3' & \\
Ncam-123F & 5'-GGGAACTCCATCAAGGTGAA-3' & $143 \mathrm{bp}$ \\
Ncam-123R & 5'-TTGAGCATGACGTGGTCACT-3' & \\
Psmb6-F* & 5'-CCACGATCACATCTTCTGCT-3' & $119 \mathrm{bp}$ \\
Psmb6-R* & 5'-GGACTAGTGGAGGCTCGTTC-3' & \\
\hline
\end{tabular}

TABLE 3

\section{PRIMERS USED FOR SIGNALING PATHWAY} GENE EXPRESSION ANALYSIS

\begin{tabular}{llc} 
Primer & Primer sequence (5'-3') & Product size \\
\hline Akt1-F & 5'-TCACCTCTGAGACTGACACCA-3' & $108 \mathrm{bp}$ \\
Akt1-R & 5'-GCTCACTGTCCACACACTCC-3' & \\
P38 $\alpha-\mathrm{F}$ & 5'-CTGTTGCTGACCCTTATGACC-3' & $136 \mathrm{bp}$ \\
P38 $-\mathrm{R}-\mathrm{R}$ & 5'-GGTGCTCAGGACTCCATTTC-3' & \\
Plc $\gamma-\mathrm{F}$ & 5'-TCCGAGCTTGTGGTCTACTG-3' & $156 \mathrm{bp}$ \\
Plc $\gamma-\mathrm{R}$ & 5'-CCGGTTGTACTGGAGGAACT-3' & \\
Mapk1-F & 5'-TTACTGCGCTTCAGACATGAG-3' & $114 \mathrm{bp}$ \\
Mapk1-R & 5'-AAGGTCCGTCTCCATGAGGT-3' & \\
Mapk3-F & 5'-AGGGCTACACCAAATCCATC-3' & $132 \mathrm{bp}$ \\
Mapk3-R & 5'-GGGAACCCAAGATACCTAGAA-3' & \\
\hline
\end{tabular}

This effect might be through the interaction between NCAM and other cell surface receptors such as FGFRs, and thus the colocalization of NCAM with FGFR2 (Fig. 3 B,D and 4F) presented in this paper indicate the possibility of a functional interaction between the two proteins in mouse early embryo development.

Next the post-fertilization expression and co-localization of NCAM and FGFR2 were investigated. The NCAM (Fig. 4B) and FGFR2 (Fig. 4D) protein expression were confirmed in mouse 2cell embryos using primary antibodies recognizing intracellular epitopes of the two proteins. Thus both NCAM and FGFR2 are present in the membrane of 2-cell mouse embryos. Co-localization studies were performed using a pair of primary antibodies recognizing intracellular epitopes of NCAM and FGFR2. Positive 

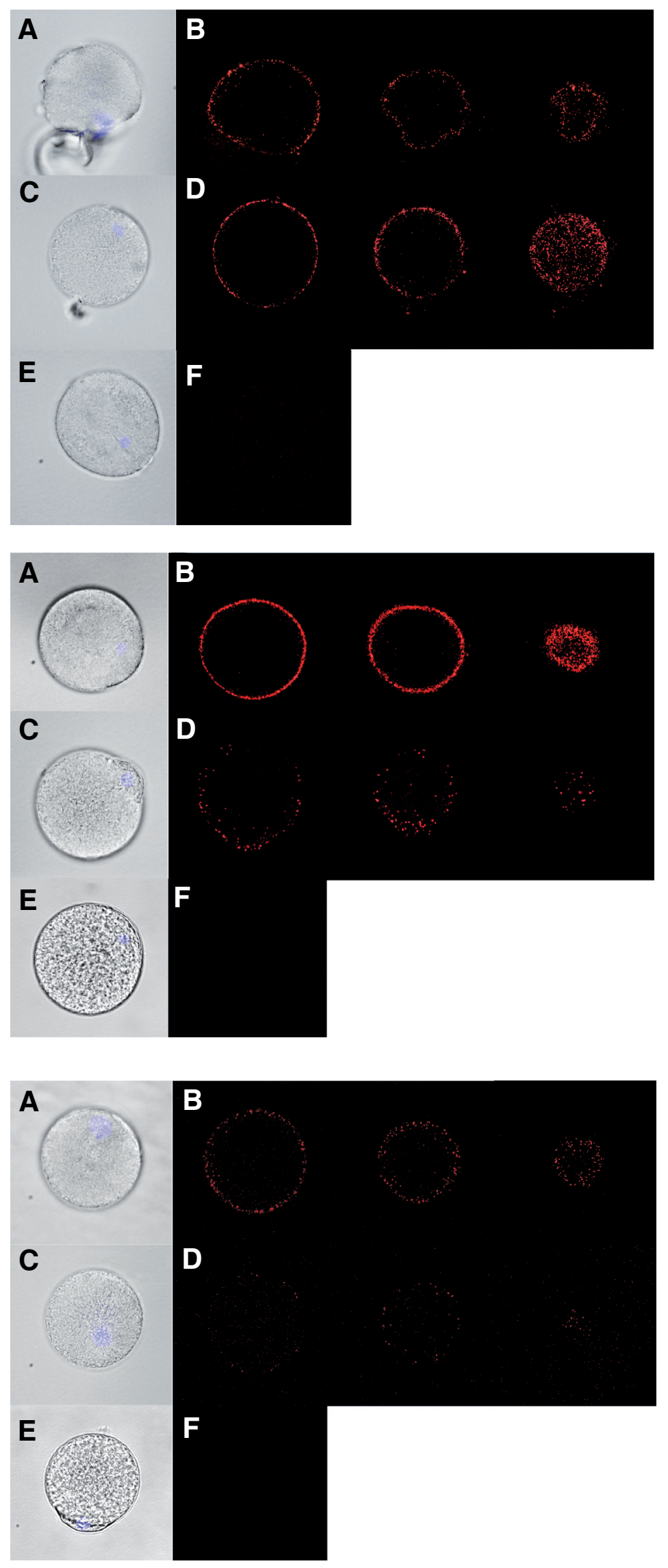

signals were observed in the membrane (Fig. 4F), thus demonstrating the co-localization of NCAM and FGFR2 in mouse 2-cell embryos. Interestingly, in the 2-cell embryos the interaction was detected only in the membrane facing the surroundings (Fig. 4F), and not in the membrane located between the two cells. It has been shown earlier using a rat myoblast cell line that FGFR1 and NCAM do not co-localize at points of cell-cell contact (Sanchez-Heras et al., 2006), thus our observation may indicate a function of the NCAMFGFR2 complex in the cellular response to extracellular factors.

To investigate the presence of Fgfr2 and Ncam transcripts mRNA expression of Ncam and different Fgfr2 isoforms were analyzed using quantitative real-time PCR (qRT-PCR). The Ncam-123 primer pair was used to detect all three Ncam transcripts (Ncam-140, -120 and -180). Primer sequences are given in Table 2. The expression of Ncam transcripts was detected at similar levels in oocyte and 2-cell embryos, while the Fgfr2-1 (IIIC) isoform was shown to be more abundant in oocytes (Fig. 5A). In addition, in oocytes the Fgfr2-1 isoform was significantly higher expressed than the Fgfr2-2 (IIIb)

Fig. 1 (Left Top). Intracellular single protein epitope detection in oocytes. (A) Bright field image merged with DAPI staining. (B) Confocal images of NCAM intracellular epitope detected in oocyte membrane, stepwise acquired sections from the middle and moving towards the end of the oocyte, with three sections selected to show membrane localization. (C) Bright field image merged with DAPI staining of oocyte. (D) Confocal images of intracellular epitope of FGFR2 detected in oocyte membrane, stepwise acquired from the middle moving towards the end of the oocyte, with three sections selected to show membrane localization. (E) Bright field image merged with DAPI staining. (F) PLA negative control. Confocal images were taken in Z-stack planes (20 per oocyte) providing overlapping optical sections approximately $3 \mu \mathrm{m}$ thick to show the membrane location of respective protein detected.

Fig. 2 (Left Middle). Extracellular single protein epitope detection in oocytes. Confocal images were taken in Z-stack planes $(20$ per oocyte) providing overlapping optical sections approximately 3 $\mu \mathrm{m}$ thick. (A) Bright field image merged with DAPI staining. (B) Confocal images of NCAM extracellular epitope detected on oocyte membrane, stepwise acquired from the middle and moving towards the end of the oocyte, with three sections selected to show membrane localization. (C) Bright field image merged with DAPI staining. (D) Confocal images of the extracellular epitope of FGFR2 detected on oocyte membrane. (E) Bright field image merged with DAPI staining of negative control oocytes. (F) PLA negative control.

Fig. 3 (Left Bottom). Co-localization of NCAM and FGFR2 in oocytes. (A)Bright field image merged with DAPI staining. (B) Confocal images of single oocyte proximity ligation assay (PLA) with primary antibodies directed towards intracellular NCAM and FGFR2 epitopes, stepwise acquired from the middle and moving towards the end of the oocyte, with three sections selected to show membrane localization. (C) Bright field image merged with DAPI staining; (D) Confocal image of PLA using antibodies recognizing extracellular NCAM and FGFR2 epitopes. Confocal images were taken in Z-stack planes (20 per oocyte) providing overlapping optical sections approximately $3 \mu \mathrm{m}$ thick to illustrate membrane location of the protein detected. Three sections are selected to show membrane localization. (E) Bright field image merged with DAPI staining of negative control. (F) Negative PLA control. 
isoform (Fig. 5A). The same pattern was observed for the 2-cell embryos, with Fgfr2-1 showing significantly higher expression (Fig. 5A). This is in concordance with a previous study observing the presence of Fgfr2-1 and Fgfr2-2 during early zygotic transcription (Haffner-Krausz et al., 1999). This difference in relative expression of Fgfr2 isoforms seems to be more pronounced in oocytes compared to 2-cell embryos (Fig. 5A) indicating that Fgfr2-1 is a more abundant maternal FGFR2 transcript than Fgfr2-2. FGFR2-2 primarily binds FGF10 and FGF7, whereas FGFR2-1 binds FGF2 (Ohuchi et al., 2000, Yan et al., 1993, Yeh et al., 2003) thus enabling a differential embryo response according to the specific FGFR2 isoform expressed. In addition, studies show that Fgfr2 expression becomes asymmetrical along the animal-vegetal axis of the mature blastocyst (Haffner-Krausz et al., 1999) suggesting a role for the different FGFR2 isoforms in the orientation and polarity of the preimplantation embryo. The mouse Fgfr2 knockout produced a recessive embryonic lethal mutation with a normal development up until blastocyst stage (Arman et al., 1998). Homozygous embryos die a few hours after implantation indicating that FGFR2 is required for early postimplantation development.

Previous studies have shown that homophilic binding of NCAM triggers signaling events that result in cellular responses such as differentiation and survival (Ditlevsen et al., 2007, Pedersen et al., 2004). These events have not been thoroughly characterized but are hypothesized to occur both via direct activation of downstream signaling cascades and via interactions with other cell surface receptors such as FGFRs (Hansen et al., 2008a). In an in vitro study by Christensen et al., (2006) using recombinant NCAM (F3 module 1-2) and FGFR2 (Ig module 2-3) proteins it was shown that the binding between the recombinant proteins had $\mathrm{Kd}$ values similar to that of NCAM-FGFR1 binding indicating that NCAM might activate FGFR2 in a similar manner as it activates FGFR1. NCAM-induced neurite outgrowth has been shown to depend on at least two FGFR-mediated pathways, the phospholipase C gamma (PLC $\gamma$ )-PKC pathway and the FRS2/SHCA MAPK path-

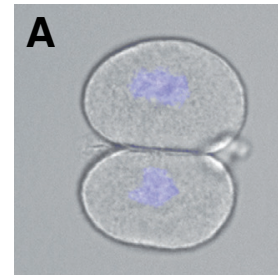

E
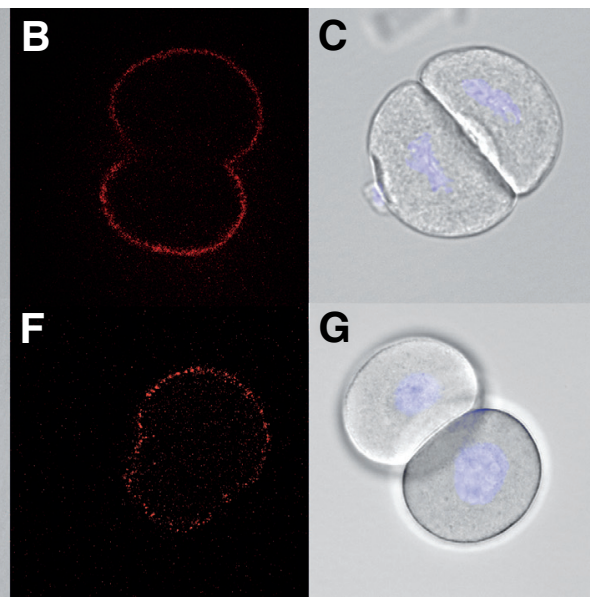

way (Kiryushko et al., 2006), suggesting NCAM interacts with FGFR to induce the activation of several FGFR downstream pathways. In this study five signaling molecules involved in the downstream signaling pathways were investigated using qRTPCR. Primer sequences are given in Table 3. A low relative level of $P l c \gamma$ expression was detected in oocytes and 2-cell embryos (Fig. 5B). It has been speculated that NCAM participates in FGFR-induced signaling by binding to PLC $\gamma$, thereby bringing FGFR and PLC $\gamma$ into close proximity of each other (Hansen et al., 2008a). However, a direct interaction between NCAM and FGFR1 was demonstrated only recently by surface plasmon resonance and nuclear magnetic resonance (Hansen et al., 2008b, Kiselyov et al., 2003). The mRNA for thymoma viral proto-oncogene 1 $(A k t 1)$, which is involved in downstream signaling of both NCAM and FGFR1 (Ditlevsen et al., 2003), and the three Map kinases, mitogen-activated protein kinase 14 (Mapk14; P38 $\alpha$ ), a component of the Fgf-signaling pathway, mitogen-activated protein kinase 1 (Mapk1 or Erk2) and mitogen-activated protein kinase 3 (Mapk3 or Erk1) were all expressed in both oocytes and 2-cell embryos (Fig. 5B). Mapk3 was expressed at significantly higher levels than the other signaling pathway components in oocytes. In addition, Mapk3 showed significantly higher mRNA expression in oocytes compared to 2-cell embryos (Fig. 5B). It has been shown previously that the entire MAPK pathway is present during mouse preimplantation development (Wang et al., 2004). Interestingly, NCAM stimulation has been shown to phosphorylate and thereby activate ERK1/2 (Kolkova et al., 2000). Although relatively little is known about possible specific roles of these two major Erk isoforms, they are co-expressed in almost all tissues at different levels. During zebrafish embryogenesis Erk1 has been shown to be ubiquitously expressed and unable to compensate for the loss of Erk2, which is temporally regulated (Krens et al., 2008) indicating specific roles for the different Erks during early development. This is in agreement with the observed higher levels of Mapk3 in oocytes compared to 2-cell embryos, showing that the expression of Mapk3 is regulated during early development in mouse (Fig.

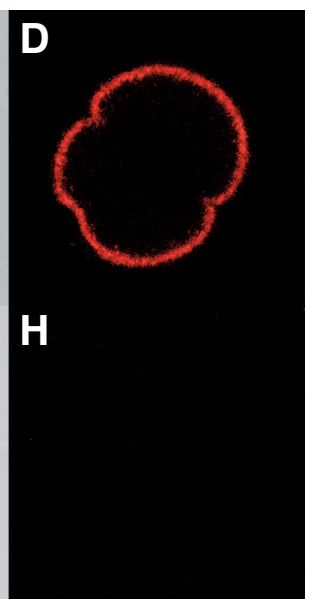

Fig. 4. Co-localization of NCAM and FGFR2 in 2-cell mouse embryos. (A) Bright field image merge with DAPI staining. (B) Confocal image of FGFR2 intracellular epitope detected using PLA. (C) Bright field image merged with DAPI staining. (D) Confocal image of NCAM intracellular epitope detected using PLA. (E) Bright field image merged with DAPI staining. (F) Confocal image of intracellular epitopes of NCAM and FGFR2 detected in membrane of 2-cell embryo. (G) Bright field image merged with DAPI stain. (H) Confocal image of PLA negative control on 2-cell embryo.
$5 \mathrm{~B})$. However, the relative expression level of Mapk1 is similar in both developmental stages.

To summarize, this study describes for the first time an in vivo close association between NCAM and FGFR2 in the membrane of mouse oocytes and 2-cell embryos using a novel adaptation of the PLA method. It is estimated that the antibody epitopes need to be a few tens of $\mathrm{nm}$ apart to be detected in a standard in situ PLA reaction (Soderberg et al., 2008). In addition, the presence of Ncam, different Fgfr2 isoforms and several downstream components of the intracellular Ncam/Fgfr2 signaling pathways are shown. Our data indicates differential expression of Fgfr2 isoforms during development and the temporal regulation of Mapk3. With these differences in expressed Fgfr2 isoforms and the observed significantly higher expression of Mapk3 over Mapk1 further strengthens the concept of differentially expressed genes during early 
A

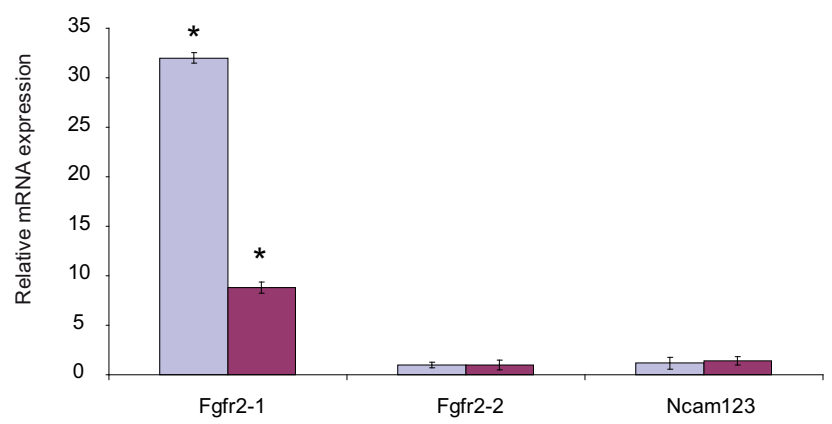

B

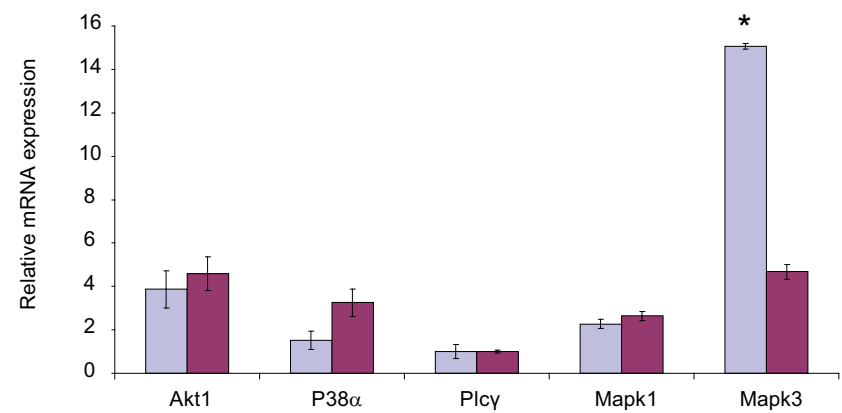

Fig. 5. Relative mRNA expression of receptor isoforms and pathway components. (A) Relative expression of Fgfr2 and Ncam. qRT-PCR showing relative $m R N A$ expression of Fgfr2 isoforms Fgfr2-1 and Fgfr22, and Ncam123 (Ncam-140,-120 and-180) in mouse oocytes and 2-cell embryos. Results shown are means \pm standard deviations of mRNA expressions levels normalized to reference gene Psmb6 expression and relative to Fgfr2-2 mRNA expression that is selected as 1. Samples are pools of five oocytes (blue bars) or 2-cell embryos (purple bars) from four to five pools in each category $\left.{ }^{*} p<0.05\right)$. (B) Relative $m R N A$ expression of signaling pathway components. qRT-PCR showing Akt1, P38 $\alpha$, Plcy, Mapk1 and Mapk3 mRNA expression in mouse oocytes and 2-cell embryos. Results shown are means \pm standard deviations of mRNA expressions levels normalized to reference gene Psmb6 expression and relative to Plcy $m R N A$ expression that is selected as 1. Samples are pools of five oocytes (blue bars) or 2-cell embryos (purple bars) from four to five pools in each category $\left.{ }^{*} p<0.05\right)$.

development. In concordance with the findings in this study we have recently performed a genome-wide expression study on stages of early human development and could detect multiple copies of both NCAM and FGFR2 isoforms during oocyte maturation and in preimplantation embryos (Table 1). Future studies are aimed at further characterizing the mechanism of NCAMFGFR2 interaction and the role of this interaction in early vertebrate development.

\section{Materials and Methods}

\section{Animal treatment and preparation of embryos}

Mature female FVB/N mice (Jackson Laboratories) were used as oocyte donors. Ovarian stimulation was performed by intra-peritoneal administration of 5 IU Pregnant Mare's Serum (Folligon, Intervet). After 48 hours, the mice were injected intra-peritoneal with human chorionic gonadotropin (hCG) $5 \mathrm{IU}$ (Chorulon, Intervet). The female mice were sacrificed 18-19 hours later by cervical dislocation and the oviducts were transferred to petri dishes with M-2 medium (Chemicon, Millipore). For later stage embryos, the female mice were allowed to mate with FVB/N males directly after hCG injection and in the following morning the mice were examined for vaginal plugs, a time point counted as day 1 (1-cell stage). Embryos were collected day 2 (2-cell stage) by flushing the uterine horns connected to oviducts with $\mathrm{M}-2$ medium under a stereomicroscope (Leica MX, 12.5). The cumulus cells complexes were dissolved with hyaluronidase enzyme at a concentration of $0.3 \mathrm{mg} / \mathrm{ml}$ (Sigma-Aldrich) and the embryos were thereafter held at $37^{\circ} \mathrm{C}$ in KSOM media (Chemicon, Millipore) covered with ovoil-100 (Vitrolife, Englewood). The animals were treated in accordance with Swedish law and regulations of the Karolinska Institutet. The mice were kept under controlled light and temperature conditions with free access to food and water. The research protocol was approved by the Swedish Ethical Board.

\section{Single oocyte proximity ligation assay (PLA)}

The zona was removed from the oocytes using acidified Tyrodes solution (Medicult) followed by three washes in PBS containing $3 \mathrm{mg} / \mathrm{m}$ polyvinylpyrrolidone (PBS-PVP). All steps were performed in droplets and the oocytes were moved between droplets using a transfer pipette under a stereomicroscope. Fixation was done using 4\% paraformaldehyde in PBS for 15 minutes at room temperature. Permeabilization was performed for 20 minutes at room temperature using PBS-PVP containing Triton X-100. Blocking was done in a $5 \%$ dilution of goat sera in PBS with $0.01 \%$ Tween 20 for 30 minutes at room temperature. The primary antibodies were diluted and incubation in the antibody solution was performed at $4^{\circ} \mathrm{C}$ over night. The primary antibodies used were: mouse NCAM (1:100, intracellular, ab9018, Abcam), rabbit FGFR2 (1:300, intracellular, ab10647, Abcam), rat NCAM (1:300, extracellular, H28, IM0270, Beckman Coulter) and rabbit FGFR2 (1:100, extracellular, ab5476, Abcam). All antibody dilutions were made in 5\% goat sera and $0.01 \%$ Tween 20 in PBS. After primary antibody incubation oocytes were washed 3 times 10 minutes in blocking buffer containing $5 \%$ goat sera, followed by incubation with the appropriate pair of plus and minus oligonucleotide-conjugated secondary antibodies (anti-mouse, anti-rabbit or anti-rat) from Olink Bioscience. In brief, by using oligonucleotideconjugated secondary antibodies specific detection of single proteins or protein-protein interaction are made possible (see Soderberg et al., 2006 for more detailed description). The oligonucleotide-conjugated secondary antibodies are annealed only when the targeted proteins are in close proximity of each other, i.e when the specific primary antibodies have bound proximal epitopes. The annealing and amplification step initiates a rolling-circle amplification, which makes it possible to detect the proteinprotein interaction using Cy3-labeled oligo-linkers (Duolink Detection kit 563 , Olink Bioscience). These fluorescently labeled oligo-linkers will bind to the amplification product from the annealed oligonucleotide-conjugated antibodies, thus only visualizing the targeted proteins when the proteins are within close proximity of each other. After the detection incubation, the oocytes were washed in $0.25 \%$ Tween 20 in PBS, 3 times 10 minutes at room temperature. Control experiments were included in all studies by omitting the primary antibodies from overnight hybridization in order to test the background given by the PLA probes. In co-localization studies, one of the two primary antibodies was omitted in the control experiments. The oocytes were mounted with Duolink ${ }^{\mathrm{TM}}$ mounting medium (Olink Bioscience) and thereafter kept in $-20^{\circ} \mathrm{C}$. The images were using a confocal scanning microscope (LSM510, Zeiss) and an inverted microscope for fluorescence and DIC (IX71, Olympus). The same PLA procedure was used for 2-cell embryos. In seven separate PLA experiments an average of 25 oocytes were used. For 2-cell embryos an average of 15 embryos were used in four separate PLA experiments. Images shown are representative of all experiments.

\section{RNA extraction, reverse transcription and quantitative real-time PCR}

MII mouse oocytes and 2-cell embryos were each put in numbers of five in $5 \mu$ l of RNAlater (Ambion) prior to RNA extraction. Total RNA was extracted from a total of four to five pools of oocytes or embryos using the RNeasy Plus Micro Kit (Qiagen) with addition of carrier RNA according to 
protocol. Elution of total RNA was done using $14 \mu \mathrm{l}$ RNase-free water. cDNA was synthesized using SuperScript III First-Strand synthesis system with random hexamer and oligo $(\mathrm{dT})_{20}$ primers (Life Technologies). For each sample, $8 \mu \mathrm{l}$ of RNA was reverse-transcribed into cDNA at $50^{\circ} \mathrm{C}$ in a reaction volume of $20 \mu \mathrm{l}$. qRT-PCR measurements of individual cDNAs were performed on the 7500 Fast Real-Time PCR System (Applied Biosystems) using a $10 \mu \mathrm{l}$ mixture containing SYBR green PCR master mix (Applied Biosystems), $1 \mu \mathrm{l} \mathrm{cDNA}$ and $0.1 \mu \mathrm{M}$ forward and reverse primers. Primers were designed using Primer3 software (Rozen and Skaletsky, 2000) and were used after having proven to be equally efficient by calibration curves. Melting curve analysis and agarose gel electrophoresis was performed to ensure correct PCR product. The PCR products were sequenced using BigDye Termination v3.1 kit (Applied Biosystems) to confirm gene identity. Each PCR reaction was performed in duplicate in two different runs with negative controls. Relative expression of the different gene transcripts was calculated by the delta-delta-Ct $(\Delta \Delta \mathrm{Ct})$ method and converted to the relative expression ratio $\left(2^{-\Delta \Delta C t}\right)$. All data were normalized to the endogenous reference gene Proteasome (prosome, macropain) subunit beta type-6 (Psmb6) expression. The Ctvalues for $P s m b 6$ expression varied from 29.5 to 31.5 in both oocyte- and 2 -cell samples. Data is represented as the mean of each sample assayed in duplicate \pm s.e.m.

\section{Statistical analysis}

Statistical significance was performed using the unequal, two-tailed students-t-test included in the excel software package (Microsoft).

\section{Acknowledgements}

We would like to express our gratitude towards José Inzunza and Ingegerd Fransson for their technical assistance. This study was supported by the Swedish Research Council, the Research funds of Stockholm County and Karolinska Institutet (ALF) and in part performed at the Live Cell Imaging unit, Department of Biosciences and Nutrition, Karolinska Institutet, Huddinge, Sweden, supported by grants from the Knut and Alice Wallenberg Foundation, the Swedish Research Council and the Centre for Biosciences.

\section{References}

ARMAN, E., HAFFNER-KRAUSZ, R., CHEN, Y., HEATH, J.K. and LONAI, P. (1998). Targeted disruption of fibroblast growth factor (FGF) receptor 2 suggests a role for FGF signaling in pregastrulation mammalian development. Proc Natl Acad Sci USA 95: 5082-5087.

BEN-HAROUSH, A., ABIR, R., AO, A., JIN, S., KESSLER-ICEKSON, G., FELDBERG, D. and FISCH, B. (2005). Expression of basic fibroblast growth factor and its receptors in human ovarian follicles from adults and fetuses. Fertil Steril 84 Suppl 2: 1257-1268.

CAILLIAU, K., LE MARCIS, V., BEREZIAT, V., PERDEREAU, D., CARIOU, B. VILAIN, J.P., BURNOL, A.F. and BROWAEYS-POLY, E. (2003). Inhibition of FGF receptor signalling in Xenopus oocytes: differential effect of Grb7, Grb10 and Grb14. FEBS Lett 548: 43-48.

CHRISTENSEN, C., LAURIDSEN, J.B., BEREZIN, V., BOCK, E. and KISELYOV, V.V. (2006). The neural cell adhesion molecule binds to fibroblast growth factor receptor 2. FEBS Lett 580: 3386-3390.

CREMER, H., LANGE, R., CHRISTOPH, A., PLOMANN, M., VOPPER, G., ROES, J., BROWN, R., BALDWIN, S., KRAEMER, P., SCHEFF, S. et al., (1994). Inactivation of the N-CAM gene in mice results in size reduction of the olfactory bulb and deficits in spatial learning. Nature 367: 455-459.

DITLEVSEN, D.K., BEREZIN, V. and BOCK, E. (2007). Signalling pathways underlying neural cell adhesion molecule-mediated survival of dopaminergic neurons. Eur J Neurosci 25: 1678-1684.

DITLEVSEN, D.K., KOHLER, L.B., PEDERSEN, M.V., RISELL, M., KOLKOVA, K., MEYER, M., BEREZIN, V. and BOCK, E. (2003). The role of phosphatidylinositol 3 -kinase in neural cell adhesion molecule-mediated neuronal differentiation and survival. J Neurochem 84: 546-556.
DITLEVSEN, D.K., POVLSEN, G.K., BEREZIN, V. and BOCK, E. (2008). NCAMinduced intracellular signaling revisited. J Neurosci Res 86: 727-473.

HAFFNER-KRAUSZ, R., GORIVODSKY, M., CHEN, Y. and LONAI, P. (1999). Expression of Fgfr2 in the early mouse embryo indicates its involvement in preimplantation development. Mech Dev 85: 167-172.

HANSEN, S.M., BEREZIN, V. and BOCK, E. (2008a). Signaling mechanisms of neurite outgrowth induced by the cell adhesion molecules NCAM and Ncadherin. Cell Mol Life Sci 65: 3809-3821.

HANSEN, S.M., KOHLER, L.B., LI, S., KISELYOV, V., CHRISTENSEN, C., OWCZAREK, S., BOCK, E. and BEREZIN, V. (2008b). NCAM-derived peptides function as agonists for the fibroblast growth factor receptor. J Neurochem 106: 2030-2041.

HINSBY, A.M., BEREZIN, V. and BOCK, E. (2004). Molecular mechanisms of NCAM function. Front Biosci 9: 2227-2244.

KIRYUSHKO, D., KORSHUNOVA, I., BEREZIN, V. and BOCK, E. (2006). Neural cell adhesion molecule induces intracellular signaling via multiple mechanisms of Ca2+ homeostasis. Mol Biol Cell 17: 2278-2286.

KISELYOV, V.V. (2010). NCAM and the FGF-receptor. Adv Exp Med Biol 663: 6779 .

KISELYOV, V.V., SKLADCHIKOVA, G., HINSBY, A.M., JENSEN, P.H., KULAHIN, N., SOROKA, V., PEDERSEN, N., TSETLIN, V., POULSEN, F.M., BEREZIN, V. et al., (2003). Structural basis for a direct interaction between FGFR1 and NCAM and evidence for a regulatory role of ATP. Structure 11: 691-701.

KOLKOVA, K., NOVITSKAYA, V., PEDERSEN, N., BEREZIN, V. and BOCK, E. (2000). Neural cell adhesion molecule-stimulated neurite outgrowth depends on activation of protein kinase $\mathrm{C}$ and the Ras-mitogen-activated protein kinase pathway. J Neurosci 20: 2238-2246.

KRENS, S.F., HE, S., LAMERS, G.E., MEIJER, A.H., BAKKERS, J., SCHMIDT, T. SPAINK, H.P. and SNAAR-JAGALSKA, B.E. (2008). Distinct functions for ERK1 and ERK2 in cell migration processes during zebrafish gastrulation. Dev Biol 319: 370-383.

LU, D.P., TIAN, L., O'NEILL, C. and KING, N.J. (2002). Regulation of cellular adhesion molecule expression in murine oocytes, peri-implantation and postimplantation embryos. Cell Res 12: 373-383.

MANESS, P.F. and SCHACHNER, M. (2007). Neural recognition molecules of the immunoglobulin superfamily: signaling transducers of axon guidance and neuronal migration. Nat Neurosci 10: 19-26.

MIKI, T., BOTTARO, D.P., FLEMING, T.P., SMITH, C.L., BURGESS, W.H., CHAN A.M. and AARONSON, S.A. (1992). Determination of ligand-binding specificity by alternative splicing: two distinct growth factor receptors encoded by a single gene. Proc Natl Acad Sci USA 89: 246-250.

MURAKAMI, M., ELFENBEIN, A. and SIMONS, M. (2008). Non-canonical fibroblast growth factor signalling in angiogenesis. Cardiovasc Res 78: 223-231.

OHUCHI, H., HORI, Y., YAMASAKI, M., HARADA, H., SEKINE, K., KATO, S. and $\mathrm{ITOH}, \mathrm{N}$. (2000). FGF10 acts as a major ligand for FGF receptor $2 \mathrm{lllb}$ in mouse multi-organ development. Biochem Biophys Res Commun 277: 643-649.

PEDERSEN, M.V., KOHLER, L.B., DITLEVSEN, D.K., LI, S., BEREZIN, V. and BOCK, E. (2004). Neuritogenic and survival-promoting effects of the P2 peptide derived from a homophilic binding site in the neural cell adhesion molecule. $J$ Neurosci Res 75: 55-65

POLO-PARADA, L., BOSE, C.M., PLATTNER, F. and LANDMESSER, L.T. (2004) Distinct roles of different neural cell adhesion molecule (NCAM) isoforms in synaptic maturation revealed by analysis of NCAM $180 \mathrm{kDa}$ isoform-deficient mice. J Neurosci 24: 1852-1864.

RABINOWITZ, J.E., RUTISHAUSER, U. and MAGNUSON, T. (1996). Targeted mutation of Ncam to produce a secreted molecule results in a dominant embryonic lethality. Proc Natl Acad Sci USA 93: 6421-6424.

ROZEN, S. and SKALETSKY, H. (2000). Primer3 on the WWW for general users and for biologist programmers. Methods Mol Biol 132: 365-386.

SANCHEZ-HERAS, E., HOWELL, F.V., WILLIAMS, G. and DOHERTY, P. (2006) The fibroblast growth factor receptor acid box is essential for interactions with $\mathrm{N}$-cadherin and all of the major isoforms of neural cell adhesion molecule. J Biol Chem 281: 35208-35216.

SCHMID, R.S., GRAFF, R.D., SCHALLER, M.D., CHEN, S., SCHACHNER, M., HEMPERLY, J.J. and MANESS, P.F. (1999). NCAM stimulates the Ras-MAPK 
pathway and CREB phosphorylation in neuronal cells. J Neurobio/ 38: 542-558. SoderberG, O., GULlBerG, M., JARVIUS, M., RIDDERSTRALE, K., LEUCHOWIUS, K.J., JARVIUS, J., WESTER, K., HYDBRING, P., BAHRAM, F., LARSSON, L.G. et al., (2006). Direct observation of individual endogenous protein complexes in situ by proximity ligation. Nat Methods 3: 995-1000.

SODERBERG, O., LEUCHOWIUS, K.J., GULLBERG, M., JARVIUS, M., WEIBRECHT, I., LARSSON, L.G. and LANDEGREN, U. (2008). Characterizing proteins and their interactions in cells and tissues using the in situ proximity ligation assay. Methods 45: 227-232.

WANG, Y., WANG, F., SUN, T., TROSTINSKAIA, A., WYGLE, D., PUSCHECK, E. and RAPPOLEE, D.A. (2004). Entire mitogen activated protein kinase (MAPK) pathway is present in preimplantation mouse embryos. Dev Dyn 231: 72-87.

YAN, G., FUKABORI, Y., MCBRIDE, G., NIKOLAROPOLOUS, S. and MCKEEHAN, W.L. (1993). Exon switching and activation of stromal and embryonic fibroblast growth factor (FGF)-FGF receptor genes in prostate epithelial cells accompany stromal independence and malignancy. Mol Cell Biol 13: 4513-4522.

YEH, B.K., IGARASHI, M., ELISEENKOVA, A.V., PLOTNIKOV, A.N., SHER, I., RON, D., AARONSON, S.A. and MOHAMMADI, M. (2003). Structural basis by which alternative splicing confers specificity in fibroblast growth factor receptors. Proc Natl Acad Sci USA 100: 2266-2271.

YOSHIDA, Y., MIYAMURA, M., HAMANO, S. and YOSHIDA, M. (1998). Expression of growth factor ligand and their receptor mRNAs in bovine ova during in vitro maturation and after fertilization in vitro. J Vet Med Sci 60: 549-554.

ZHANG, P., ZUCCHELLI, M., BRUCE, S., HAMBILIKI, F., STAVREUS-EVERS, A., LEVKOV, L., SKOTTMAN, H., KERKELA, E., KERE, J. and HOVATTA, O. (2009). Transcriptome profiling of human pre-implantation development. PLOS One 4: e7844. 


\section{Further Related Reading, published previously in the Int. J. Dev. Biol.}

See our recent Special Issue Animal Cloning \& Cell Reprogramming edited by Michele Boiani and José B. Cibelli at:

http://www.ijdb.ehu.es/web/contents.php?vol=54\&issue=11-12

Comprehensive analysis of fibroblast growth factor receptor expression patterns during chick forelimb development Sheeba CJ, Andrade RP, Duprez D, Palmeirim I.

Int J Dev Biol. (2010) 54:1517-26

An activating mutation in the PDGF receptor-beta causes abnormal morphology in the mouse placenta

Camilla Looman, Tong Sun, Yang Yu, Agata Zieba, Aive Ahgren, Ricardo Feinstein, Henrik Forsberg, Carina Hellberg, Carl-Henrik Heldin, Xiao-Qun Zhang, Karin Forsberg-Nilsson, Nelson Khoo, Reinald Fundele and Rainer Heuchel

Int. J. Dev. Biol. (2007) 51: 361-370

Collective cell migration in morphogenesis and cancer

Peter Friedl, Yael Hegerfeldt and Miriam Tusch

Int. J. Dev. Biol. (2004) 48: 441-449

Differential expression of neural cell adhesion molecule (NCAM) during osteogenesis and secondary chondrogenesis in the embryonic chick

$\mathrm{J}$ Fang and B K Hall

Int. J. Dev. Biol. (1995) 39: 519-528

Expression of isoforms of the neural cell adhesion molecule (NCAM) and polysialic acid during the development of the Bufo arenarum olfactory system

D A Paz, D G Alonso, A Pisano, V H Casco, K A Knudsen and A Peralta Soler

Int. J. Dev. Biol. (1995) 39: 1005-1013

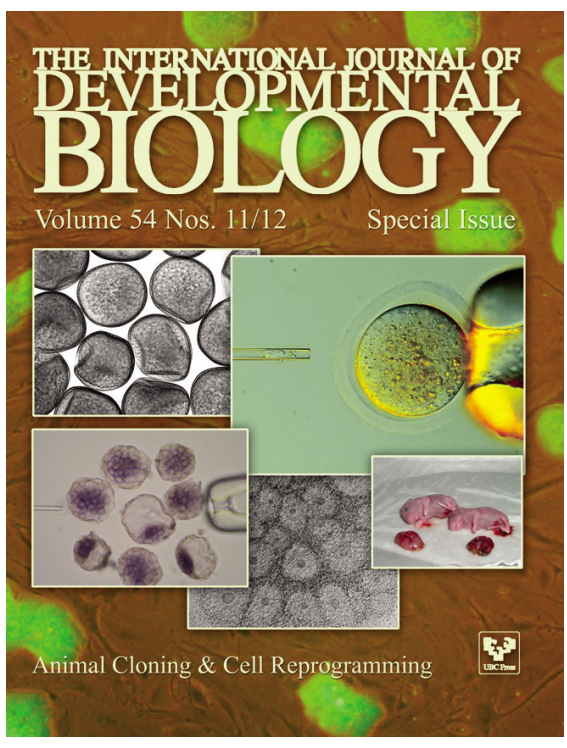

5 yr ISI Impact Factor $(2009)=3.253$

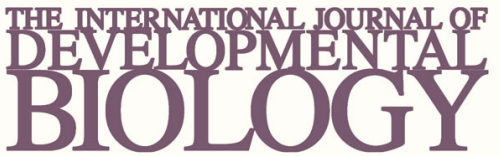

Volume 54 Nos. 6/7

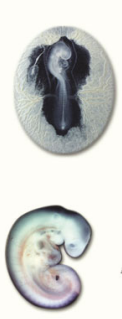

Special Issue

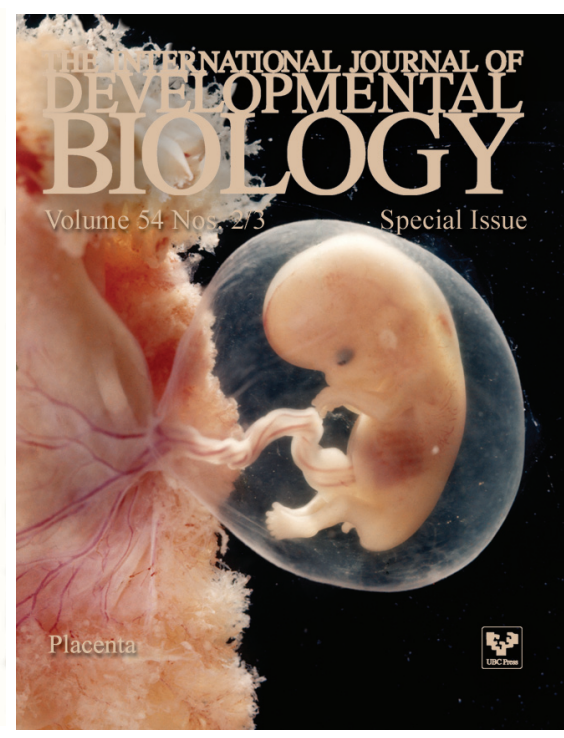

